\title{
Features of vascular remodelling in the patients with arterial hypertension in a case of brain stroke
}

\author{
I. V. Drozdova
}

State Institution "Ukrainian State Institute of Medical and Social Problems of Disability Ministry of Public Health of Ukraine”, Dnipro, Ukraine

Key words:

stroke,

hypertension,

atherosclerosis.

Zaporozhye

medical journal

2017; 19 (5), 564-569

DOI:

10.14739/2310-1210

2017.5.110089

E-mail:

drozdova@ua.fm
Purpose of research - to determine the features and factors which influence the vascular remodelling in patients with arterial hypertension in the late restoration period of brain stroke, taking into account an intima-media complex thickness.

Materials and methods. The research enrolled 44 patients with stage III AH in the restoration period of a brain stroke. All participants underwent ultrasound examination of the brachycephalus arteries, daily monitoring of arterial pressure, Doppler echocardiography. Patients were divided into 2 groups: the I group included 24 patients $(54.5 \%)$ with normal thickness of complex intima-media (CIM), the II group - 20 (45.5\%) patients with thickness of CIM >0.9 mm.

Results. In the patients with stage III AH in a case of brain stroke thickening of CIM was in $45.5 \%$, concentric hypertrophy-in $25.0 \%$ and remodelling - in $10.0 \%$. Daily profiles of AP such as night-peaker were observed in $20.0 \%$ of patients, an over-dipper - in $5.0 \%$, which indicated an unfavourable prognosis regarding repeated cases of the cardiovascular events. Structural and functional features in the vessels of patients with stage III AH were formed under an influence of both diastolic and systolic dysfunction of $\mathrm{LV}$, hypertrophy and concentric remodelling, presence, duration and an inadequate treatment of $\mathrm{AH}$, anthropometric and other risk factors in the patients with $\mathrm{AH}$ in the restoration period of a brain stroke, which requires a rigorous tactic of their correction.

Conclusions. Determination of the factors affecting structural and functional peculiarities of vessels in the patients with $\mathrm{AH}$, together with commonly accepted risk factors, should be on a basis to assess their rehabilitation potential, stratification of a common cardiovascular risk, development of an individual rehabilitation program for disabled people with this pathology. Further, the role, character, prognosis and effectiveness of the revealed features correction in the patients with arterial hypertension in the restoration period of a brain stroke should be clarified.

\section{Киючові слова:} мозковий інсульт, артеріальна гіпертензія, атероскиероз.

Запорізький медичний журнал. - 2017. T. 19, № 5(104). C. 564-569

\section{Особливості ремоделювання судин у хворих на артеріальну гіпертензію з перенесеним інсультом}

\section{І. В. Ароздова}

Артеріальна гіпертензія (АГ) та атеросклероз (особливо перенесений мозковий інсульт) фрормують структурно-функціональні зміни екстракраніальних артерій, але сьогодні особливості ремоделювання судин у хворих на АГ у віддалений період мозкового інсульту (MI) вивчені недостатньо.

Мета роботи - визначити особливості й чинники впливу на ремоделювання судин у хворих на артеріальну гіпертензію в пізньому відновному періоді інсульту з урахуванням товщини комплексу інтима-медіа.

Матеріали та методи. 44 хворим на АГ III стадії в пізньому відновному періоді Мl здійснили ультразвукове дослідження брахіоцефальних артерій, добове моніторування артеріального тиску та доплерехокардіографічне дослідження. Хворих поділили на 2 групи: перша включала 24 пацієнти (54,5%) з нормальною товщиною комплексу інтима-медіа (КІМ), друга група - 20 (45,5\%) осіб із КІМ >0,9 мм.

Результати. У хворих на АГ III стадії з МІ потовщення КІМ виявили у 45,5 \%, концентричну гіпертрофію - у 25,0 \%, ремоделювання - у 10,0 \%, добові профілі артеріального тиску night-peaker - у 20,0 \%, over-dipper - у 5,0 \% обстежених, що свідчило про несприятливий прогноз у них щодо повторних серцево-судинних подій. Структурно-функціональні особливості судин у хворих на АГ ІІІ стадії фрормувались під впливом як діастолічної, так і систолічної диссфункції ЛШ, гіпертрофрії ЛШ і концентричного ремоделювання, наявності, тривалості, неадекватного лікування АГ, антропометричних та інших фракторів ризику хворих на АГ у віддаленому періоді Мl, що потребує жорсткої тактики їх корекції.

Висновки. Визначення чинників впливу на структурно-функціональні особливості судин у хворих на АГ поряд із загальноприйнятими факторами ризику має бути в основі визначення їхнього реабілітаційного потенціалу, стратиффікації загального серцево-судинного ризику, розробки індивідуальних програм реабілітації інвалідів із цією патологією. Надалі необхідно уточнити роль, характер, прогноз й ефрективність корекції виявлених особливостей у хворих на АГ у віддаленому періоді Мl.

Киючевые слова: мозговой инсульт, артериальная гипертензия, атеросклероз.

Запорожский медицинский журнал. - 2017. -

T. 19, № 5(104). C. 564-569

\section{Особенности ремоделирования сосудов у больных артериальной гипертензией с перенесенным инсультом}

\section{И. В. Ароздова}

Артериальная гипертензия (АГ) и атеросклероз при перенесенном мозговом инсульте (МИ) формируют структурно-функциональные изменения экстракраниальных артерий, но даже сегодня особенности ремоделирования сосудов у больных АГ в отдаленный период МИ недостаточно изучены.

Цель работы - определить особенности и факторы, влияющие на ремоделирование сосудов у больных артериальной гипертензией в позднем восстановительном периоде инсульта с учетом толщины комплекса интима-медиа. 
Материалы и методы. У 44 больных АГ III стадии в позднем восстановительном периоде МИ проводили ультразвуковое исследование брахиоцефальных артерий, суточное мониторирование артериального давления и допплерэхокардиографрическое исследование. Больные были разделены на 2 группы: первая включала 24 пациента (54,5\%) с нормальной толщиной комплекса интима-медиа (КІМ), вторая группа - 20 (45,5 \%) лиц с КИМ >0,9 мм.

Результаты. У больных АГ ІІІ стадии з МИ утолщение КИМ встречалось у 45,5 \%, концентрическая гипертрофия - у $25,0 \%$ и ремоделирование - у 10,0 \%, суточные профили артериального давления night-peaker - у 20,0 \% и overdipper - y 5,0 \% обследованных, что свидетельствовало о неблагоприятном прогнозе повторных сердечно-сосудистых событий. Структурно-функциональные особенности сосудов у больных АГ III стадии формировались под влиянием как диастолической, так и систолической диссункции ЛЖ, концентрического ремоделирования и гипертрофии, наличия, длительности и неадекватного лечения АГ, антропометрических и других фракторов риска у больных АГ отдаленном периоде МИ, что требует жесткой тактики их коррекции.

Выводы. Изучение факторов, влияющих на структурно-функциональные особенности сосудов у больных АГ, наряду с общепринятыми факторами риска, должно быть в основе определения их реабилитационного потенциала, стратифрикации общего сердечно-сосудистого риска, разработки индивидуальных программ реабилитации инвалидов с этой патологией. В дальнейшем необходимо уточнить роль, характер, прогноз и эффективность коррекции выявленных особенностей у больных АГ в отдаленном периоде МИ.

Arterial hypertension $(\mathrm{AH})$, atherosclerosis and especially a brain stroke (BS) form numerous morphofunctional changes (remodelling) in the extracranial arteries, such as a common carotid artery (CCA), which result in increase of their diameter and decrease of vascular wall elastic properties $[3,4,8,10,11]$. Today, it is well known a relationship between complex of intima-media (CIM), the carotid arteries and risk factors for BS development $[7,9,11,14]$. One of the most sensitive determinants in possibility of cardiovascular events repeated cases occurrence in persons with $\mathrm{AH}$ is consider an intensity of the heart and blood vessels remodelling, size and severity of the endothelial dysfunction and the processes of atherosclerosis and arteriosclerosis $[6,7,9,11,13]$. Probability to assess the intensity of heart and blood vessels remodelling for a long period of time was focused on the serial measurement of heart, blood vessels walls and cavities thickness and kinetics, analysis of their relaxation characteristics on a background of physical loading, hyperventilation, reactive hyperemia or other pharmacological stress tests [3,5,8-11].

I. N. Dykan, L. V. Melnykova, T. S. Mishchenko, E. V. Pisotska, M. Tendera considered, that thickness of CIM is a specific sonographic marker of early atherosclerotic lesion of vascular wall, indicating about prevalence of atherosclerosis. Its increase varies depending on age, duration and stage of $\mathrm{AH}$, body mass index and coronary arteries pathology, blood glucose concentration, presence of diabetes, smoking, etc. $[5,8,9,11,16]$. Thickening CIM of CCA is connected with a risk of cardiovascular disease, regardless of the lifestyle, social and other risk factors. Numerous epidemiological studies have been shown, that CIM thickness is associated with a risk of acute myocardial infarction and cerebral ischemic stroke [16,17].

Some of the heart and blood vessels remodelling indicators, which are traditionally assessed by using a duplex impulse or tissue Doppler echocardiography, have a great predictive meaning of the cardiovascular risk development $[4,8,11]$. To determine the character of blood pressure daily profile, correlation of deformation and frequency of the myocardium deformation with genetic factors, with comorbid pathology and cognitive dysfunction in patients with $\mathrm{AH}$, could have a significant, but limited value to assess occurrence of the repeated cardiovascular events $[6,7,9,11,17]$. Therefore, this article review sheds new light on the potential prognostic markers and factors, which influence the morphofunctional condition of the blood vessels in the patients with $\mathrm{AH}$ in case of brain stroke.

Purpose of research - to determine the features and factors which influence the vascular remodelling in the patients with arterial hypertension in the late restoration period of brain stroke, taking into account an intima-media complex thickness.

\section{Materials and methods}

An open controlled research was conducted on a basis of State Institution "Ukrainian State Research Institute of Medico-Social Problems of Disability Ministry of Health of Ukraine" in the framework of informed consent. Retrospective study enrolled 44 patients with stage III $\mathrm{AH}$ in the restoration period of a brain stroke. An inclusion criterion in the research was essential $\mathrm{AH}$ in patients aged from 30 to 59 years. Exclusion criteria: secondary forms of $\mathrm{AH}$; renal arteries stenosis; persistent form of atrial fibrillation; severe kidney and liver functions violations; myocardial infarction, cardio surgical interventions; decompensated diabetes; presence of the comorbidities, which could influence survival rate and quality of patients' life within 3 months; presence of marked cognitive impairment and psychiatric pathology; treatment refusal. All patients received information and signed informed consent to participate in the research.

$\mathrm{AH}$ was diagnosed according to the requirements of $\mathrm{Na}$ tional guidelines: "Guidance and Clinical Protocol of Medical Care: Arterial Hypertension", recommendations of Ukrainian Association of Cardiologists (2013) and recommendations of the European Society of Cardiologists (2013), adapted clinical guidance "Modern Principles of Diagnostic and Treatment Patients with Acute Ischemic Stroke and TIA", the Standard Clinical Protocol of Medical Care "Ischemic Stroke" [14].

Surveyed groups of patients included: $22(50.0 \%)$ persons with a delayed consequences of brain infarction (l.69.3); 9 (20.5\%) patients with delayed consequences of intra-cerebral hemorrhage (I.69.1); 3 (6.8 \%) - with delayed effects of subarachnoid hemorrhage (I.69.0); 2 $(4.5 \%)$ - with unknown diagnoses of brain hemorrhage or infarction (l.69.4); 1 (2.3\%) - in the late restoration period of brain infarction or stroke, caused by thrombosis of brain arteries (I.63.3); 1 (2.3\%) - in the late restoration period of subarachnoid hemorrhage (I.60); $5(11.3 \%)$ - with delayed consequences of non - traumatic intracranial hemorrhages 
Table 1. Factors which influence vascular remodelling in the patients with arterial hypertension in the late restoration period of a brain stroke depending on the intima-media complex thickness

\begin{tabular}{lll}
\hline $\begin{array}{l}\text { Indexes of vessels } \\
\text { Remodelling, }\end{array}$ & \multicolumn{2}{l}{ Patients with arterial hypertension and ischemic stroke } \\
\cline { 2 - 3 } units of measurement & $\begin{array}{l}\text { I group } \\
(\mathbf{n}=\mathbf{2 4})\end{array}$ & $\begin{array}{l}\text { II group } \\
(\mathbf{n}=\mathbf{2 0})\end{array}$ \\
\hline D RCCA, cm & $0.70 \pm 0.01$ & $0.76 \pm 0.01^{* *}$ \\
Vs RCCA, cm/sec & $89.77 \pm 2.24$ & $82.61 \pm 2.16^{*}$ \\
Ri RCCA & $0.72 \pm 0.01$ & $0.74 \pm 0.02$ \\
D LCCA, cm & $0.69 \pm 0.01$ & $0.73 \pm 0.01$ \\
Ri LCCA & $0.72 \pm 0.01$ & $0.75 \pm 0.01$ \\
D RICA, cm & $0.50 \pm 0.01$ & $0.54 \pm 0.01$ \\
Vs RICA, cm/sec & $73.61 \pm 1.23$ & $70.06 \pm 2.31$ \\
Ri RICA & $0.71 \pm 0.01$ & $0.73 \pm 0.01$ \\
D LICA, cm & $0.51 \pm 0.01$ & $0.53 \pm 0.01$ \\
Vs LICA, cm/sec & $74.72 \pm 1.24$ & $71.97 \pm 2.15$ \\
Ri LICA & $0.71 \pm 0.01$ & $0.73 \pm 0.01$ \\
D RVA, cm & $0.36 \pm 0.01$ & $0.35 \pm 0.01$ \\
Vs RVA, cm/sec & $44.45 \pm 1.34$ & $43.37 \pm 1.56$ \\
Ri RVA & $0.71 \pm 0.01$ & $0.71 \pm 0.01$ \\
D LVA, cm & $0.36 \pm 0.01$ & $0.34 \pm 0.01$ \\
Vs LVA, cm/sec & $44.20 \pm 1.48$ & $43.23 \pm 1.86$ \\
Ri LVA & $0.71 \pm 0.01$ & $0.74 \pm 0.01$ \\
CIM, cm & $0.07 \pm 0.001$ & $0.12 \pm 0.004$ \\
\hline
\end{tabular}

(I.69.2); 1 (2.3\%) - in the late restoration period of brain stroke, as well as unknown myocardial infarction or hemorrhage (I.64); 1 (2.3\%) - in the late restoration period of intracerebral hemorrhage, intraventricular hemorrhage (I.61.5).

All patients underwent daily monitoring of blood pressure (DMBP) on the apparatus ABPM-1 (Meditech, Hungary) [15], Doppler echocardiography on the apparatus Sonos (Philips) [12], ultrasonic scanning of the brachiocephalic arteries - on the apparatus LOGIC 5P PRO (USA) [16].

Ultrasonic scanning of the brachiocephalic arteries was performed on the apparatus LOGIC R5 PRO (GE, USA) using a linear sensor with the range $5-10 \mathrm{MHz}$. Research was carried out by standard method - in the patient's position lying on back. In accordance with the standard method of B-mode ultrasonography carotid and vertebral arteries were investigated: a vascular geometry, lumen and diameter of the arteries, complex of intima-media (CIM) thickness, anomalies of blood vessels development. For hemodynamic parameters characteristic pulse wave Doppler was applied with the following assessment of the blood flow spectrum, measurement of peak systolic (Vps) and end-diastolic (Ved) velocities, calculation of the peripheral resistance index (RI) and systolic and diastolic ratio (S/D) by the formulas: $\mathrm{RI}=(\mathrm{Vps}-\mathrm{Ved}) / \mathrm{Vps} ; \mathrm{S} / \mathrm{D}=\mathrm{Vps} / \mathrm{Ved}[16]$.

By carotid lesions presence patients with stage III AH in a case of the brain stroke were divided into 2 groups: the I group included 24 patients (54.5\%) with the normal thickness of $\mathrm{CIM}$, the II group -20 (45.5\%) patients with $\mathrm{CIM}>0.9 \mathrm{~mm}$.

Statistical analysis was performed using Statistica 6.1 license program (StatSoft Inc, USA). Parametrical Student t-criterion was applied to compare results between studied groups for independent samples. Correlation between indicators was determined using Pearson's correlation coefficient. There were performed the level of statistical significance $p<0.05[1,2]$.

\section{Results and discussion}

Affection of carotid arteries (thickening of CIM $>0.9 \mathrm{~mm}$ ) in patients with BS has been found in $20(45.5 \%)$ persons (II group). On the other hand, 24 patients (54.5\%) have not had the damage of carotid arteries (I group). Majority of patients from the I and II groups had atherosclerotic plaques in the carotid arteries $[14,16,17]$.

M. M. Dolzhenko considered, that all patients with $\mathrm{AH}$, complicated by ischemic stroke, have a statistically significant higher thickness of CIM CCA, comparing with healthy people, regardless of the stroke substrate. It was corresponded to the presence of different localization hemodynamically insignificant $(<50 \%)$ stenosis in $50.3 \%$ of cases without statistically significant asymmetry of blood flow [4].

Diameter of the right common carotid artery (D RCCA) in the II group of patients increased by $8.49 \%(p<0.01)$ (Table 1), which correlated with a numerous factors: anthropometric (waist circumference); heart remodelling (aortic root diameter, systolic valve opening, left atrial size, end-diastolic and end-systolic size of left ventricular (LV), end-diastolic volume of $L V$, its index, end-systolic and percussive volumes of $L V$, posterior wall of LV thickness, its relative thickness and interventricular septum thickness, myocardium mass of LV, its index) and vessels (diameters of the left common, right and left internal carotid arteries (ICA). The following factors have been taken into account: loading by pressure (daily and night systolic (SAP) and diastolic (DAP) arterial pressure $(A P))$, time indices, daily variability of DAP, daily minimum, average and maximum SAP and DAP, an average AP and pulse arterial pressure (PAP).

Velocity of a blood flow in the right common carotid artery (Vs RCCA) in the II group of examined patients decreased by $7.97 \%(p<0.05)$, which was associated with the such factors as: anthropometric (waist circumference); the heart remodelling (aortic root diameter, systolic valve opening, left atrial size, end-diastolic and end-systolic size of left ventricular (LV), end-diastolic volume of LV, its index, end-systolic and percussive volumes of $L V$, posterior wall of $L V$ thickness, its relative thickness and interventricular septum thickness, myocardium mass of LV, its index, area of right atrium and its index) and vessels (diameters of the right and left CCA, blood flow velocity in the left common and right and left internal carotid arteries (ICA), in the right and left vertebral arteries (VA). It is also included loading by pressure (daily DAP, time indices SAP and DAP, daily average DAP and average $A P$, area index of SAP).

Resistance index of the right common carotid artery (Ri RCCA) in the II group of patients increased by $3.19 \%$, which was associated with heart remodelling (thickness of the interventricular septum) and vessels (resistance index of left CCA and right ICA, right VA, diameter and resistance index of left VA).

Velocity of blood flow in the left common carotid artery (Vs LCCA) in the II group of patients decreased by $10.75 \%$ $(p<0.001)$, which was associated with such factors as: anthropometric (body weight, waist circumference); heart remodelling (gradient of pressure on mitral valve, transtricuspid blood flow velocity and in pulmonary artery, gradient of pressure in pulmonary artery, size, index and area index of left atrium, end-diastolic size and volume of LV, indexes of end-diastolic and percussive volumes of $L V$, posterior wall of LV thickness, its relative thickness and interventricular sep- 
tum thickness, myocardium mass of $L V$, its index, area of right ventricular) and vessels (blood flow velocity in the right and left ICA, in the right and left VA, in the right CCA, diameters of the right and left CCA).

The Vs LCCA could be also associated with the next factors: loading by pressure (daily SAP and DAP, their time indices, night SAP and DAP, daily average SAP and DAP, average $A P$, maximum $D A P$, the area index of $D A P$, average heart rate $(H R)$.

Comparing parameters of vascular remodelling in the patients with stages II and III AH O. O. Lisova revealed that vascular wall elasticity demonstrated statistically significant differences. Other vascular remodelling parameters in the patients with stage III AH were lower, than in the patients with stage II $\mathrm{AH}$, but there were no significant differences between indicators of CIM CCA in both groups of patients [8]. M. M. Dolzhenko demonstrated, that patients with $\mathrm{AH}$ and ischemic stroke have statistically significant lower diameter of CCA and distensibility coefficient, a higher index of stiffness, compared with healthy people. This fact indicates a progressive remodelling of arterial blood flow in patients with $\mathrm{AH}$, complicated by ischemic stroke [4].

Diameter of the right internal carotid artery (D RICA) in the II group of patients increased by $8.14 \%(p<0.01)$, which was associated with a heart remodelling (left ventricular index) and vessels (diameters of the right and left CCA, left ICA, blood flow velocity in the left ICA and right VA); with loading by pressure (time indices and daily variability of DAP, daily average and maximum DAP and average AP).

Complex of intima-media (CIM) in the II group of patients increased by $77.27 \%(p<0.001)$ and was varied in average $0.117 \pm 0.04 \mathrm{~mm}$. This one was correlated with heart remodelling (end-diastolic size of LV) and vessels (diameter of the left CCA).

M. M. Dolzhenko study demonstrated, that the worst indicators of extra cranial arteries remodelling in the patients with brain stroke by stiffness index were statistically significant correlated with systemic atherosclerosis progression in terms of CIM thickness of CCA [4].

According to the data of daily AP monitoring, among non-specific persons (the I group) and among persons with CIM thickening (the II group), there were the following patients with daily AP profile: non-dipper - $8(33.3 \%)$ and $6(30.0 \%)$, night-peaker $-2(8.33 \%)$ and $4(20.0 \%)$, dipper - $13(54.17 \%)$ and $9(45.0 \%)$, over-dipper - 1 (4.2 and $5.0 \%$ respectively.

It has been shown in the patients from the II group the increase in a daily SAP and DAP by $8.53 \%(p<0.001)$ and by $6.59 \%(p<0.05)$; time indices SAP and DAP - by 122.88 and $95.91 \%(p<0.05)$, variability of SAP - by 10.83 . Similar trend has been observed for the same indicators at night: in persons of the II group increase in night indicators of SAP - by $9.43 \%(p<0.05)$ and DAP - by $7.19 \%$; time indices SAP and DAP - by 51.6 and $58.26 \%$, variability of SAP and DAP - by 9.71 and $6.18 \%$ respectively.

It has been revealed that in the patients from the II group day SAP and DAP were significantly higher. Minimum, average and maximum day SAP and DAP in this group of patients increased by 2.11 and $3.36 \%(p>0.05)$; by $7.41 \%(p<0.05)$ and $5.25 \%$; by $8.98 \%(p<0.001)$ and $7.32 \%(p<0.05)$, respectively. Day minimum, average and maximum average and pulse AP have had a similar trend: in the II group of pa- tients they increased by 4.53 and $7.81 \% ; 1.72$ and $6.57 \%$; 4.62 and $10.63 \%$ respectively. However, in the patients from the II group the frequency of heart contractions was slightly reduced by $2.57 \%$.

Certain features of heart remodelling were typical for both groups of patients. Among persons with normal CIM thickness (the I group) and with CIM thickening (the II group) totally it has been observed: 62.5 and $45.0 \%$ of patients without LV hypertrophy; 20.9 and $20.0 \%$ - with eccentric hypertrophy, 8.3 and $25.0 \%$ - with concentric hypertrophy; 8.3 and $10.0 \%$ - with concentric remodelling.

In the research work of $\mathrm{O}$. O. Lisova it has been shown that among patients with $\mathrm{AH}$ complicated by brain stroke a high frequency of prognostically unfavourable form of myocardium concentric hypertrophy, pseudonormal mitral flow profile, an insufficient reduction of night blood pressure, even in a case of controlled $\mathrm{AH}$ by the inpatient measurements, had been observed [8].

M. M. Dolzhenko showed, that in the patients with $\mathrm{AH}$ with ischemic stroke typical changes have been found, such as increased LV posterior wall thickness and myocardium mass index, a large size of LV cavities, decreased global LV contractility, increased LV filling pressure and values of average pressure in the small circle of blood circulation, size of right ventricle cavity [4].

In comparison with the I group, in the patients of the II group diameter of aortic root was increased by $3.44 \%$; systolic opening of the semilunar - by $3.81 \%$; maximum blood flow velocity - by $3.63 \%$ and pressure gradient on the aortic valve - by $9.21 \%$. In the patients with stage III AH (the II group) the size, index, area and a area index of left atrium were increased by $9.11 \%(p<0.001), 5.03 ; 11.33$ and $7.94 \%$ respectively.

End-diastolic size and volume, indexes of end-diastolic size and volume in the patients with stage III AH were increased by 4.42; 0.08; 7.09 and $4.63 \%(p<0.05)$, respectively, which corresponded to the II group. In this patients with stage III AH, end-systolic size and volume were increased in case of CIM thickening in 5.65 and $11.40 \%$, respectively, compare with the group of patients with normal CIM thickness. In comparison with the I group, patients with stage III AH, who concerned to the II group, had the following changes: increasing in stroke volume by $2.30 \%$, decreasing in ejection fraction by $3.94 \%$, respectively.

Myocardium posterior wall thickness, relative thickness of myocardium, interventricular septum thickness were increased by $5.65 ; 0.70 ; 5.60 \%(p>0.05)$ respectively, in the patients with stage III AH, i.e. the II group. LV myocardium mass and myocardium mass index were increased by $16.09 \%(p<0.05)$ and $10.35 \%$, respectively, in the II group of patients with stage III AH. In the II group of patients end-diastolic size of $\mathrm{RV}$, area of a right atrium and the right atrium area index were increased by $8.59 \%$ and $13.81 \%$ $(p<0.01)$, and on $7.38 \%$, respectively, comparing with the same indicators in the I group of patients.

M. M. Dolzhenko's research demonstrates that patient with $\mathrm{AH}$, complicated with ischemic stroke, has a statistically significant reduction of peripheral hemodynamic and the higher peak systolic and diastolic blood flow velocity and time averaged maximum of blood flow velocity in CCA with the lower resistance and pulse indexes [4]. A weak, but statistically significant correlation between the thickness 
of CIM CCA and relative thickness of LV wall, presence of LV hypertrophy indicated that heart remodelling and systemic atherosclerosis progression in a case of $\mathrm{AH}$ could be the parallel process. On the other hand, they are the different links of common pathogenetic mechanism. They should be evaluated comprehensively in the patients with $\mathrm{AH}$ and ischemic stroke for the common cardiovascular risk stratification $[4,6,7]$.

In the conclusion, it should be noted, that in the patients with stage III AH in the restoration period of a brain stroke CIM thickening was observed in half of the cases among examined patients. The atherosclerotic plaques of carotid arteries with a different localization hemodynamically insignificant stenosis without significant blood flow asymmetry were defined almost in all patients. Persons with CIM thickening were characterized by increased diameter by $8.49 \%$ $(p<0.01)$ and decreased blood flow velocity by $7.97 \%$ $(p<0.05)$ in the right CCA. Trend towards increasing of the diameters and indices of CCA and ICA resistance with blood flow velocity decreasing has shown a progressive arterial remodelling in the patients with $\mathrm{AH}$ in case of ischemic stroke. These features were formed under the influence of LV diastolic and systolic dysfunction (increase in size and index of left atrium, end-diastolic size and volume, end-systolic size and index of end-diastolic LV volume); LV concentric remodelling and hypertrophy (increase in thickness of myocardium posterior wall and interventricular septum, mass and myocardial mass index). It was also determined by the presence, duration and an inadequate treatment of $\mathrm{AH}$ (achievement of AP target level was observed only in $50 \%$ of examined patients, violations of daily rhythms in a form of night-peaker and over-dipper), by the anthropometric and other risk factors in the patients with $\mathrm{AH}$ in the restoration period of a brain stroke. Determination of factors and character of their influence on a vascular remodelling in the patients with $\mathrm{AH}$ not only in the early stages of disease, but also in a case of severe complications, should be on a basis to assess their rehabilitation potential, common cardiovascular risk stratification, individual rehabilitation program development for the patients with disabilities.

\section{Conclusions}

1. In patients with stage III AH in the restoration period of a brain stroke CIM thickening was observed in half of cases among examined patients, and atherosclerotic plaques of carotid arteries with different localization hemodynamically insignificant stenosis without significant asymmetry of blood flow were defined almost in all patients. This fact indicated a progressive arterial remodelling in the patients with $\mathrm{AH}$ in case of ischemic stroke.

2. Mainly among patients with stage III AH in case of brain stroke CIM thickening was in $45.5 \%$, the concentric hypertrophy - in $25.0 \%$ and remodelling - in $10.0 \%$. Daily AP profiles were observed as well as night-peaker - in $20.0 \%$ of patients, over-dipper - in $5.0 \%$, which indicated an unfavourable prognosis regarding repeated cases of the cardiovascular events.

3. Structural and functional features in the vessels of patients with stage III AH were formed under an influence of both LV diastolic and systolic dysfunction, LV hypertrophy and concentric remodelling, presence, duration and an inadequate treatment of $\mathrm{AH}$, anthropometric and other risk factors in the patients with $\mathrm{AH}$ in the restoration period of a brain stroke. It requires a rigorous tactic of their correction.

4. Determination of factors which influence the structural and functional peculiarities of vessels in patients with $\mathrm{AH}$, together with commonly accepted risk factors, should be on a basis to assess their rehabilitation potential, stratification of a common cardiovascular risk, development of an individual rehabilitation program for disabled people with this pathology.

Prospects of further research involve the clarification of role, character, prognosis and effectiveness of drug and non-pharmacologic correction of the revealed features in patients with arterial hypertension in the restoration period of a brain stroke.

\section{References}

[1] Ajvazyan, S. A., Bezhaeva, Z. I., \& Staroverov, O. V. (1974). Klassificaciya mnogomernykh nablyudenij [Classification of multidimensional supervisions]. Moscow: Statistica. [in Russian]

[2] Babak, V. P., Biletskyi, A. Ya., Prystavka, O. P., \& Prystavka, P. O (2001). Statystychna obrobka dannykh [Statistical processing of data]. Kyiv: MBBTS [in Ukrainan].

[3] Vayda, L. S., Lozinska, N. V., Habriel, M. V., \& Gay, O. I. (2015). Pokaznyky dobovoho monitoruvannia arterialnoho tysku, lipidnoho spektra krovi, vazodylatatorna funktsiia endoteliiu ta indeks masy tila u khvorykh na arterialnu hipertenziiu na tli likuvannia karvedylolom i atenololom [The parameters of the 24 hours blood pressure monitoring, blood lipid spectrum, endothelial vasodilator function and body mass index in patients with arterial hypertension under treatment with carvedilol and atenolol]. Ukrainskyi kardiolohichnyi zhurnal, 4, 55-60. [in Ukrainian].

[4] Dolzhenko, M. M., Grubyak, L. M., \& Sokhor, N. R. (2016). Morfofunktsionalnyi stan ekstrakranialnykh arterii u khvorykh na arterialnu hipertenziiu pislia perenesenoho ishemichnoho insultu [Morphological and functional extracranial arteries changes in hypertensive patients after ischemic stroke]. Ukrainskyi kardiolohichnyi zhurnal, 5, 44-49. [in Ukrainian].

[5] Dican, I. N. (2013). Vozrastnye osobennosti izmenenij kompleksa intima-media obschikh sonnykh arterij $\vee$ period reabilitacii posle perenesennogo ishemicheskogo insul'ta [Age-dependent features of changes of complex of intima-media of general carotids in the period of rehabilitation after the carried ischemic stroke]. Problemy stareniya i dolgoletiya, 3, 294-300. [in Russian].

[6] Kovalenko, V. M., Nesukay, E. G., Polenova, N. S., Titov, E. Yu., \& Danylenko, O. O. (2014). Vzaiemozv'iazok mizh strukturno-funktsionalnym stanom livykh viddiliv sertsia i tolerantnistiu do fizychnoho navantazhennia v patsiientiv z hipertonichnoiu khvoroboiu [Relationship of structural and functional state of left heart to exercise tolerance in patients with essential hypertension]. Ukrainskyi kardiolohichnyi zhurnal, 4, 26-32. [in Ukrainian].

[7] Kovalenko, V. M., Nesukay, E. G., Titov, E. Yu., Polenova, N. S., \& Danylenko, O. O. (2014). Osoblyvosti strukturno-funktsionalnoho stanu livykh viddiliv sertsia u patsiientiv z hipertonichnoiu khvoroboiu z riznymy typamy remodeliuvannia [Features of structural and functional state of the left heart in hypertensive patients with different types of remodeling]. Ukrainskyi kardiolohichnyi zhurnal, 5, 44-49. [in Ukrainian].

[8] Lisova, O. O. (2015) Diahnostychni ta prohnostychni znachennia parametriv rekonstruktsii sertsevo-sudynnoi systemy u patsiientiv z arterialnoiu hipertenziieiu ta ishemichnym insultom (Avtoref. dis... dokt. med. nauk) [Diagnostic and prognostic value of cardiac and vascula remodeling in hypertensive patients after ischemic stroke. Dr. med. sci. diss.]. Dnipropetrovsk. [in Ukrainan]

[9] Melnikova, L. V. (2009). Structurno-funkcional'nye osobennosti obschikh sonnyhk arterij u bol'nykh e'ssencial'noj gipertenziej v zavisimostj ot velichiny sistolicheskogo arterial'nogo davleniya [The dependency of structural and functional features of common carotid arteries on systolic blood pressure in hypertensive patients]. Arterial'naya gipertenziya, 5, 51-54. [in Russian]

[10] Michenko, T. S., \& Pesotskaya, E. V. (2004) Sostoyanie magistral'nykh sosudov golov i shei u bol'nykh, pereneshikh aterotromboticheskij insul't [State of main vessels of head and neck for patients carrying an ischemic stroke]. Current issues in pharmacy and medicine: science and practice, 67, 128-132. [in Russian].

[11] Michenko, T. S., \& Pesockaya, E. V. (2007) Utolscheniye kompleksa intima-media vnutrennej sonnoj arterii kak predictor ishemicheskogo insul'ta [Bulge of complex of intima-media of internal carotid as predictor of ischemic stroke]. Praktychna anhiolohiia, 6(11), 28-37. [in Russian]. 
[12] Syvolap, V. D., Lashkul, D. A., \& Zemlyanoy, Ya. V. (2010). Kardial'noe remodelirovanie i diastolisheskaya funkciya u bol'nykh ishemischeskoj bolezn'yu serdca s arterial'noj gipertenziej [Cardiac remodeling and diastolic function in patient with ischemic heart disease and arterial hypertension]. Suchasni medychni tekhnolohii, 3(7), 26-31. [in Russian].

[13] Berezin, A. E., \& Lisovaya, O. A. (2014). Predicted Value of Serial Measurments of Circulating Vascular Endothelial Growth Factor-1 in Arterial Hypertension Patients after Acute Ischaemic stroke. Cardiovascular Medicine, 17(1), 14-20. doi: 10.4414/cvm.2014.00205.

[14] Mancia, G., Fagard, R., Narkiewicz, K., Redon, J., Zanchetti, A Böhm, M., et al. (2013) ESH/ESC guidelines for the management of arterial hypertension: the Task Force for the Management of Arterial Hypertension of the European Society of Hypertension (ESH) and of the European Society of Cardiology (ESC). Eur. Heart. J., 34(28), 2159-2219. doi: 10.1093/eurhearti/eht151.

[15] Parati, G., Stergiou, G., O'Brien, E., Asmar, R., Beilin, L., Bilo, G., et al. (2014). European Society of Hypertension practice guidelines for ambulatory blood pressure monitoring. J. Hypertens., 32, 1359-1366. doi: 10.1097/HJH.0000000000000221.

[16] Tendera, M., Aboyans, V., Bartelink, M. L., Baumgartner, I., Clément, D., Collet, J. P., et al. (2011) ESC Guidelines on the diagnosis and treatment of peripheral artery diseases: Document covering atherosclerotic disease of extracranial carotid and vertebral? Mesenteric, renal, upper and lower extremity arteries: the Task Force on the Diagnosis and Treatment of Peripheral Artery Diseases of the European Society of Cardiology (ESC). Eur. Heart. J., 32(22), 2851-2906 doi: 10.1093/eurhearti/ehr211.

[17] Zhang, Yi., Leong, H., Kretz, S., Agnoletti, D., Mourad, J. J., Safar, M. E., \& Blacher, J. (2013). Characteristics and Future Cardiovascular Risk of Patients With Not-At-Goal Hypertension in General Practice in France: The AVANT'AGE Study. J. Clin. Hypertens., 15, 291-295. doi: 10.1111/ jch.12082.

\section{Information about author:}

Drozdova I. V., MD, PhD, DSci., Head of the Department of Medico-Social Examination and Rehabilitation in Internal, Nervous Diseases and Psychosomatic Disorders, State Institution "Ukrainian State Institute of Medical and Social Problems of Disability Ministry of Public Health of Ukraine", Dnipro.

\section{Відомості про автора:}

Ароздова І. В., А-р меА. наук, старший науковий співробітник, зав. віААілу МСЕ та реабілітації при внутрішніх, нервових хворобах і психосоматичних розладах, АУ «Український Аержавний науково-АосліАний інститут меАико-соціальних проблем інвалінності М03 України", м. Аніпро.

\section{Сведения об авторе:}

АрозАова И. В., А-р меА. наук, старший научный сотрудник, зав. отАелом МСЭ и реабилитации при внутренних, нервных болезнях и психосоматических расстройствах, гу “Украинский государственный научно-исследовательский институт медикосоциальных проблем инвалиАности МЗ Украины", г. Анипро.

Конфлікт інтересів: віАсутній.

Conflicts of Interest: author has no conflict of interest to declare.

Надійшло Ао редакції / Received: 26.06.2017

Після Аоопрацювання / Revised: 04.07.2017

Прийнято Ао Аруку / Accepted: 17.07.2017 